\title{
BIOLOGIT IHMISESTÄ - TIEDETTÄ, IDEOLOGIAA VAI POLITIIKKAA?
}

MIT Press, Cambridge, Massachusetts, 1978

Tammilehto, Olli: Kasvaako vihreillä niityillä rahaa? Suomi 14-15/ 1983 s. 32-33.

Taylor, Charles: Hegel, Cambridge University Press, Cambridge 1975.

Theunissen, Michael: Gesellschaft und Geschichte, zur Kritik der kritischen Theorie, Walter de Gruyter Verlag, Berlin 1969.

Wallgren, Thomas: Emancipation genom upplysning? - Habermas filosofiska intentioner och hans kunskapsintresseteori som bas for en kritisk samhällsteori. (Filosofin lisensiaattityö, Helsinki 1985, julkaisematon. Säilytyspaikka, HY:n filosofian laitoksen kirjasto.)

Winch, Peter: The Idea of a Social Science and its Relation to Philosophy, Routledge \& Kegan Paul, London 1958

Understanding a Primitive Society. Teoksessa Winch: Ethics and Action, Routledge \& Kegan Paul, London 1972.

Wittgenstein, Ludvig: Philosophical Investigations, Blackwell, Oxford 1976.
STEVEN ROSE, R.C. LEWONTIN, LEON J. KAMIN: Not in our genes. Biology, ideology and human nature. Pantheon (USA) 1984, Penguin (England) 1984.

\section{1.}

Margareth Thatcherin ja Ronald Reaganin valtakaudet ovat merkinneet käännettä angloamerikkalaisen maailman tiederahoituksessa. Mutta mikäli kolmikkoa Steven Rose, Richard Lewontin ja Leon Kamin on uskominen, Atlantin akselilla voimistuneen uusoikeiston vaikutus tieteeseen ulottuu syvemmällekin, tutkimuksen ideologisiin lähtökohtiin sekä tuloksista vedettyjen johtopäätösten luonteeseen.

Kolmikko aloittaa vasta ilmestyneen kriittisen katsauksensa biologiseen determinismiin luvulla "uusi oikeisto ja vanha determinismi". Siinä he esittävät välittömän kytkennän biologisen determinismin uuden nousun ja poliittisten suhdanteiden muutosten välille: Uusoikeiston poliittinen voimistuminen on vastaus kapitalismia 60-luvulta lähtien ravistelleisiin kriiseihin, ja eräs oikeiston ideologian kulmakivistä on pyrkimys osoittaa maailman porvarillinen järjestys ihmisen biologisen perusluonnon määräämäksi. Oivallinen ase on biologisen determinismin vanha ajatuskulku; termiä käytetään kirjassa kattokäsitteenä kuvaamaan kaikkia yrityksiä palauttaa ihmisen sosiaalinen käyttäytyminen biologiaan.

Kritiikki on painavaa. Kirjaa ei voi sivuuttaa kukaan, joka työskentelee biologisen/yhteiskunnallisen välitysongelmien parissa. Kirjoittajat ansaitsevat esittelyn: Steven Rose on neurobiologi ja tunnettu englantilaisen 60-luvulla syntyneen radikaalin tutkijaliikkeen vaikuttajana; Tiede \& edistyksen lukijoille hänet esiteltiin haastattelussa numerossa 2/82. Richard Lewontin on evoluutiobiologi, peruskoulutukseltaan geneetikko, ja eräs populaatiogenetiikan johtavista nimistä maailmassa. Leon Kamin on psykologi, joka on tullut tunnetuksi erityisesti älykkyyden periytyvyyteen liittyvistä kriittisistä kirjoituksistaan; hän esitti $\mathrm{mm}$. ensimmäisiä epäileviä puheenvuoroja aikoinaan laajaa arvostusta nauttineita Cyril Burtin kaksostutkimuksia kohtaan - sittemminhän Burtin aineistot osoittautuivat väärennöksiksi.

Kirjasta ei kuitenkaan voi olla yksinomaan haltioitunut. Jaksot biologisen determinismin konkreettisista ilmenemismuodoista ovat painavia, mutta teoreettinen perusta herättää kysymyksiä.

\section{2.}

Kirjassa on kymmenen lukua. Näistä kolme ensimmäistä käsittelee biologisen determinismin politiikkaa sekä yleisiä historiallisia kytkentöjä porvarilliseen ideologiaan. Neljäs luku on siirtymä konkretiaan. Siinä esitetään yhteiskunnallisen eriarvoisuuden oikeuttaminen biologisen determinismin historialliseksi perusteemaksi. Sen jälkeen seuraa viisi ajankohtaisia esimerkkejä käsittelevää lukua, teemoinaan älykkyyden periytyvyys, patriarkaatti, ns. käyttäytymishäiriöiden (esimerkiksi slummiväkivallan tai koululasten yliaktiivisuuden) suhde aivofysiologiaan, skitsofrenian periytyvyys, sekä sosiobiologia. Kymmenes luku on synteesi otsikkonaan "uusi biologia vastaan vanha ideologia".

Konkreettiset jaksot ovat, kuten sanottu, kirjan paras anti, ja ne toki kattavat kaksi kolmannesta koko sivumäärästä. Etenkin älykkyyden periytymistä ja skitsofreniaa koskevia jaksoja luin paikoitellen hiukset pystyssä - siksi ratkaisevia teoreettisia ja metodologisia aukkoja kirjoittajat osoittavat näiden alojen vallitsevan viisauden päättelystä. Cyril Burtin tapausta käsitellään yksityiskohtaisesti, ja sen se toki ansaitsee; Burt sepitti kirjoituspöydän ääressä mukamas laajoihin identtisten kaksosten haastattelututkimuksiin perustuvia aineistoja, joiden nojalla hän väitti älykkyysosamäärän periytyvyyden olevan $77 \%$. Tieteelliset väärennökset eivät koskaan ole vailla yleisempää oirearvoa. Burt voidaan todeta "rikolliseksi" mutta kiintoisempaa on pohtia, miksi hänen väitteillään oli, ja on, niin laajalti vastakaikua psykologien ja perinnöllisyystieteilijöiden keskuudessa. Burtin jäljet näkyvät sitä paitsi edelleenkin. Väärennös 
paljastui sitovasti vuonna 1976 , ja sen jälkeen Burtin nimi on kadonnut arvonsa tuntevien tekijöiden lähdeluetteloista, mutta hänen tekaistut aineistonsa jatkavat elämäänsä aina vuonna 1984 julkaistuja oppikirjoja myöten joko vailla lähdeviitettä tai toisen käden lainauksina.

Psykofarmakologiaa koskeva lu$\mathrm{ku}$ on toisenluonteinen jännityskertomus, joskin yhtä vaikuttava. Siinä kirjoittajat osoittavat, miten pelottavan heppoisilla perusteilla mielisairaaloissa, vankiloissa ja jopa kouluissa on sovellettu kemiallista lääkitystä häiriintyneiksi määriteltyjen yksilöiden normalisointiin.

Sosiobiologiasta tekijät keskittyvät pääasiassa teorian loogiseen ja käsitteelliseen rakenteeseen pitäen kritiikkinsä kohteena E.O. Wilsonin alkuperäistä, vuonna 1975 julkaistua kirjaa Sociobiology. Kritiik$\mathrm{ki}$ on perusteltua ja käsitteellinen erittely osuvaa, joskin se jättää kohteestaan ehkä liian eriytymättömän kuvan. Sosiobiologian suoraviivaisimmat sovellutukset ihmiseen ja yhteiskuntaan ovat biologista determinismiä pahimmillaan, mutta sosiobiologiaan luetun tutkimuksen piirissä tehdään paljon muutakin: Eläinten sosiaalisen käyttäytymisen evoluutio on toki tärkeä biologisen tutkimuksen erityisalue.

Kirjan konkreettisista jaksoista patriarkaatille omistettu on yleisluonteisin ja siksi myös kevyin. Sitä lukiessani kaipasin enemmän ja systemaattisempia esimerkkejä biologien tavoista käsitellä ihmisen sukupuolisuutta ja sukupuolien suhteita. Hiuksianostattavaa aineistoa on tarjolla aivan riittävästi, sitä on koottuna esimerkiksi Ruth Bleierin tuoreeseen tekstiin Science and gender (Pergamon Press 1984; tämä mainoskatkona).

Tässä lyhykäisesti esiteltynä kirjan ihmisbiologinen sisältö. Se nostaa esiin ensimmäisen teoreettisen ongelman: Kestääkö näin erilaisten asioiden niputtaminen saman yleisnimikkeen, "biologisen determinismin", alle? Mielestäni ei kestä: tarvittaisiin vivahteikkaampaa ja erittelevämpää teoreettista taustaa, jonka perusteella arvioidaan ihmisbiologian eri tutkimussuuntia. Välittömimmin tämä ongelma ilmenee taipumuksena nimettömään niputtamiseen: "Biologiset deterministit" esiintyvät liian monessa yhteydessä lauseiden subjekteina ilman täsmennyksiä - kirjan marginaaliin ilmestyy valitettavan monessa kohdin lukijan kyllästynyt kysymys, "keitä he ovat?",

\section{3.}

Teoreettiset ongelmat palautuvat pohjimmiltaan itse käsitteen biologinen determinismi määrittelyyn. Se jää luvattoman kevyeksi; järjestelmällisen kehittelyn sijasta kirjoittajat vetoavat liian helposti illustroiviin esimerkkeihin, jotka usein on otettu sanomalehtiteksteistä. Toki lehtien heijastama tiedotusvälineiden mytologia on tärkeä ilmiö, mutta ei siitä teoreettisen kritiikin kohteen määrittäjäksi ole. Avaintermin määrittelylle on annettu kirjassa tilaa yksi sivu, ja sen havainnollistavina viitteinä ovat Guardianin nimetön artikkeli Englannin vuoden 1981 slummimellakoiden syistä sekä katkelma silloisen sosiaaliministeri Patrick Jenkinsin naisten työssäkäyntiä koskeneesta puheesta vuodelta 1980. Tätä edeltää puolen sivun verran kirjan toisen avainkäsitteen, reduktionismin, määrittelyä. Voiko kukaan kuvitella, että reduktionismista saa puoleen sivuun mahtumaan muuta kuin kaikkein kuluneimmat osa/kokonaisuus-pyöritykset?

Puute on kirjan teoreettisen perustan kannalta vakava. Seuraus on, että tosiasiassa tekijöiden käsite "biologinen determinismi" määrittäytyy ostensiivisesti, niiden esimerkkien kautta, joiden yhteydessä siihen tekstin eri osissa viitataan. Lukija jää ihmettelemään, ovatko esimerkiksi sosiobiologiaan varauksellisen kiinnostuneesti suhtautuvat geneetikot "biologisia deterministejä" samassa mielessä kuin Guardianin anonyymi toimittaja tai Thatcherin entinen ministeri. Jos eivät ole (kuten kaiken kohtuuden mukaan pitäisi mielestäni ajatella), niin miten tätä eroa voi täsmentää? Rose-Lewontin-Kamin eivät anna täsmentämiselle aineksia.

Kirjan peruskảsite siis hajoaa käsiin — tai pikemminkin, siitä muo- dostuu kehä: biologisia deterministejä ovat ne, jotka kannattavat biologista determinismiä, ja biologinen determinismi on sitä, mitä biologiset deterministit kannattavat.

Kirjan historialliset jaksot eivät tätä käsitteellistä epäselvyyttä korjaa, pikemminkin päinvastoin. Luvussa "The politics of biological determinism" todetaan (s. 18): "Biologinen determinismi on siis inhimillisen elämän reduktionistista selittämistä, jossa kausaalisuusnuolet kulkevat geeneistä ihmisiin ja ihmisistä ihmisyyteen. Mutta se on enemmän kuin pelkkä selitystapa: se on politiikkaa." Näin suoraviivaisia väitteitä lukiessani nielaisen kahdesti. Politiikan, ideologian ja tieteen rajat ovat veteen vedettyjä, mutta ei niitä silti yhtäläisyysmerkeiksi voi muuttaa. Kun kansallissosialisteja karrikoiva National Front on Englannissa vedonnut sosiobiologiaan, on kyse varmaankin politiikasta, ja sama astinlauta on ehkä USA:n viranomaisilla, jotka ehkäisevät vankilamellakoita pumppaamalla vangit täyteen psykofarmakologisia lääkkeitä. Mutta entä (vedotakseni aiempaan esimerkkiin) sosiobiologiaan varauksellisen kiinnostuneesti suhtautuvat geneetikot?

Tasot sekoittuvat ja vivahteet puuttuvat jaksoissa, joissa käsitellään biologisen determinismin historiallisia taustoja. Kovin oikoisia ovat kirjassa esitetyt kannat esimerkiksi determinismin yleisistä yhteyksistä porvarilliseen ideologiaan; tätä kàsittelevản luvun otsikko on "Bourgeois ideology and the origin of determinism". Jaksoja lukiessa syntyy sellainen kuva kuin kapitalismi olisi porvariston tietoisesti tuottama, ja tämän ideologiseksi perustelemiseksi on tarvittu determinismi yleensä ja biologinen determinismi erityisesti. Sivulla 68 vedetään yhden virkkeen historiallinen linja $\mathrm{Pa}$ riisiin kommuunista vuoden $68 \mathrm{ka}$ pinoihin ja todetaan: "Biologisen determinismin ideologia on kehitetty juuri vastaamaan itseoikeutuksen tarpeeseen ja estämään yhteiskunnallista epäjärjestystä."

Kirjoittajien suurta historiallista linjaa vasten biologisen determinismin uusien virtausten tiukka kytkentä päivänpolitiikkaan vaikuttaa lähes ristiriitaiselta. Uuden aallon 
synty sijoitetaan nimettyyn Arthur Jensenin artikkeliin vuodelta 1969 Harvard Educational Review'ssa ehkäpä näkökulmaan vaikuttaa se, että kaksi tekijöistä työskentelee Harvardissa? Toisella tavoin ärsyttävän yksioikoinen on toteamus Francis Crickin molekyyligeneettisiin töihin perustuvasta perinnöllisyystieteen ns. keskeisdogmista (jonka mukaan informaatiota välittyy ainoastaan nukleiinihapoista proteiineihin, mutta ei päinvastaiseen suuntaan) (s. 59): "Crickin metafora oli sopivin 1960-luvun sofistikoituneiden talouksien oloissa, joissa tuotannon pohtiminen oli vähentymässä suhteessa kontrollin ja johtamisen pohdintaan."

Näin keveillä vedoilla ei todellakaan pitäisi maalata jonkin tieteenalan piirissä laajalti hyväksyttyjen perustavien teorioiden yhteiskunnallisia kytkentöjä.

4.

Välitysten puuttuminen on siis kirjassa esitetyn tiede-ideologia-politiikka ketjun keskeinen heikkous. Kirjoittajien omaksuma - tai ainakin tekstin heijastama - näkemys on, paradoksaalisesti, reduktionistinen: Tiede palautetaan politiikkaan ja ideologiaan (joiden ero jää erinomaisen hämäräksi), olivatpa kyseessä porvariston nousua hallitsevaksi luokaksi kuvastava historiallinen kaari tai päivänpolitiikan muuttuvien voimasuhteiden mukaan vaihtuvat suhdanteet.

Tämä vie biologista determinismiä vastaan kohdistetulta kritiikiltä terää. Kritiikki ei kommunikoi sitä on hyvin vaikea suhteuttaa tieteelliseen keskusteluun, jota sitäkin sentään esimerkiksi sosiobiologian teemoista käydään. Tutkija voi(nee) vakuuttua siitä, että hänen aiemmin omaksumansa kanta on virheellinen, jos vasta-argumentit ovat riittävän painavat. Mutta kukapa myöntäisi olevansa Thatcherin tai Reaganin ideologinen (joskin tahdoton ja hyväätarkoittava) agentti?

Toisin sanoen, E.O. Wilson ei ole sosiobiologiassaan väärässä siksi, että Thatcherin ministeri voi nojautua hänen teoriaansa, vaan siksi, että teoria ei kestä yhteiskunnalli- sen eikä liioin biologisenkaan tietämyksen painetta.

Kritiikin tasot on kyettävä eriyttämään. Reduktionismí ja biologinen determinismi toki ovat biologisessa tutkimuksessa vallitsevia, ja kritiikkiä kaipaavia virtauksia. Niiden taustana olevat ja niitä kantavat käsitteelliset struktuurit, ajatustavat, tutkimusperinteet (vaihtoehtoisia lähestymistapoja on useita) tulisi penkoa esiin paljon tarkemmin ja vivahteikkaammin kuin kolmikko Rose-Lewontin-Kamin tekee. Luonnontieteen käsitteet ja ajatusmallit ovat sitovia ja viekkaita yhtä lailla kuin yhteiskuntatieteidenkin, ja siksi myös luonnontieteiden teoreettisen kehityksen on kirjoitettava koko ajan omaa historiaansa, otettava mittaa voimassa olevista ajatustavoista tunkeutuessaan niiden läpi uusiin ja toivottavasti parempiin (vaikka tämä tapahtuu näennäisesti hitaammassa tempossa kuin yhteiskuntatieteissä).

Eritoten tämä pätee ihmistä tutkiviin luonnontieteen aloihin nähden. On hyvin kyseenalaista, voiko ihmistä pitää missään mielessä puhtaan perustutkimuksen kohteena; ihminen tutkimuskohteena on aina vallitsevan käsitteellisen harson peitossa. Foucaultin ihmistieteen diskurssit vaikuttavat ihmisbiologiaankin. Biologinen determinismi on tärkeä ulottuvuus ihmistä koskevien tutkimusperinteiden arkeologiassa, ja sillä on epäilemättä ajoittain ollut keskeisen tärkeitä poliittisia ulottuvuuksia, mutta kyse on silti monista eri diskursseista, joiden spesifit yhteydet tulisi avata.

\section{5.}

Huomaan kritiikkini muodostuneen sangen kovasanaiseksi. Tämä ei merkitse, etteikö Not in our genes kuuluisi painavimpaan luokkaan biologista determinismiä käsitteleviä tekstejä. Kirjan teoreettinen perusta on mielestäni hatara, mutta voihan asian nähdä toisinkin päin: Biologisen determinismin kritiikin aineksia on nyt huomattava määrä koottuna yksien kansien väliin. Jatkettakoon tästä. Porvarillisen tieteen kritiikki kun on pähkinä, jonka sivuitse radikaaleilla tutkijoilla ei ole kulkua ja joka on jäänyt lopullisesti halkaisematta muiltakin kuin kolmikolta Rose-LewontinKamin.

Yrjö Haila 